\title{
Processing keratin from camel hair and cashmere with ionic liquids
}

\author{
Y. J. Yang ${ }^{1,2}$, D. Ganbat ${ }^{3}$, P. Aramwit ${ }^{4}$, A. Bucciarelli ${ }^{2}$, J. Chen ${ }^{2}$, C. Migliaresi $^{2,5}$, A. Motta $^{2,5^{*}}$ \\ ${ }^{1}$ Department of Industrial Engineering and BIOtech Research Center, University of Trento, Via Sommarive 9, \\ 38123 Trento, Italy \\ ${ }^{2}$ School of Environmental and Chemical Engineering, Shanghai University, No.99 Shangda Road, 200444 Shanghai, China \\ ${ }^{3}$ Department of Technical Mechanics, School of Mechanical Engineering and Transportation, Mongolian University of \\ Science and Technology, $8^{\text {th }}$ khoroo, Baga Toiruu 34, Sukhbaatar district, 14191 Ulaanbaatar, Mongolia \\ ${ }^{4}$ Bioactive Resources for Innovative Clinical Applications Research Unit and Department of Pharmacy Practice, Faculty \\ of Pharmaceutical Sciences, Chulalongkorn University, PhayaThai Road, Phatumwan, 10330 Bangkok, Thailand \\ ${ }^{5}$ European Institute of Excellence in Tissue Engineering and Regenerative Medicine, Trento Unit, Via delle Regole 101, \\ 38123 Mattarello, Trento, Italy
}

Received 11 june 2018; accepted in revised form 3 September 2018

\begin{abstract}
Keratin, a fibrous protein, that is available from a variety of animal sources as a constituent of hair, nails, horns, hoofs, wool and feathers, has applications in pharmaceutics, cosmetics and as a fertilizer. Like many naturally-derived biomaterials, the intrinsic biological activity and biocompatibility of keratin render this polymer a potential candidate for applications in medicine, and for the fabrication of scaffolds for tissue engineering. While several sources of keratin can be considered, the bioactivity of the keratins obtained can be quite different. In this study we discuss the processing and characterization of keratin from camel hair and goat cashmere. Specifically, the camel hair and cashmere were dissolved in an ionic liquid (1-butyl-3-methylimidazolium chloride), and the characteristics of the soluble and insoluble keratin were evaluated. The structure and properties of the raw material, soluble, and insoluble keratin were studied. Compared to the starting material, the soluble keratin showed chemical changes viz. decrease of cysteine, and minor structural changes. Preliminary in vitro biological properties performed by a lactate dehydrogenase (LDH) assay and scratch test showed good bioactivity in keratin from both sources. In particular, cell migration was observed to be faster when cells were cultured in the presence of soluble keratin extracted from camel hair and cashmere.
\end{abstract}

Keywords: biopolymers, keratin, dissolution, ionic liquids, animal hairs

\section{Introduction}

Keratin, a fibrous structural protein, is the major component of hair (approximately $95 \mathrm{wt} \%$ in wool [1]), feathers (approximately $90 \mathrm{wt} \%$ [2]), and the outer layer of skin, nails, horns and beaks. According to its structure and function, keratin is categorized into two groups with - i) low sulfur content (soft keratin) and ii) high sulfur content (hard keratin) [3-5]. The former is the crucial structural component of epithelial tissues [6], whereas the latter is found in nails and beaks. Different from other fibrous proteins, keratin contains high amounts of cysteine (7-20\% of total amino acid residues) $[7,8]$, mostly localized at the terminal regions of the protein $[9,10]$. Similar to other biopolymers, the intrinsic biocompatibility [11-13], biodegradability [14, 15], and natural abundance of keratin make it a valuable candidate for biomedical and tissue engineering applications $[16,17]$. The presence of the primary amino acid sequence of cellular-binding motifs, i.e. RGD (Arg-Gly-Asp), in

${ }^{*}$ Corresponding author, e-mail: antonella.motta@unitn.it (C) BME-PT 
the keratin make it useful for tissue scaffolds, by promoting cell adhesion and activation by interaction of the integrin family of proteins $\alpha 4 \beta 1$ [18-20]. The use of keratin to fabricate fibers [21], films [22], nanosized filaments [23], and gels [24, 25] has been previously investigated. In addition, keratin for biomedical applications, e.g. ocular regeneration [13], wound healing [26, 27], skin replacement [28], bone tissue engineering [29] and controlled drug delivery [30, 31] has also been reported. Natural polymers can be isolated from different sources. For example, collagen can be derived from mammals and sea organisms [32], while keratin has been typically isolated from human hair, wool and feathers [17]. However, it is well known that the final product composition and bioactivity can vary depending on the source and method of processing. The specific analysis and characterization of these natural biomaterials is therefore of importance.

Due to its three dimensional polypeptide structure which consists of a triple-helix of protein chains held together by a range of covalent (disulfide bonds) and noncovalent interactions [33, 34], keratin is stable to most solvents. Water soluble keratin from wool, hair, and feathers, can be partially extracted by alkali hydrolysis [35], enzyme-alkaline treatment [36], steam explosion [37] and the Shindai method [38]. However, some of the reagents used in these methods are toxic, difficult to remove from the substrates, or difficult to recycle. Recently, the use of ionic liquid (IL) solvents showed improvements in the dissolution process, with a higher yield of keratin from feathers $[39,40]$ and wool $[41,42]$. IL solvents provide a unique combination of properties, including low vapor pressure and high thermal stability [43]. ILs containing chloride such as 1-butyl-3-methylimidazolium chloride ([BMIM]Cl) as anion, were shown to dissolve wool better than other ILs (BF4, PF6, and $\mathrm{Br}$ ) [42, 44-46]. [BMIM] Cl itself has been proposed as an effective solvent for extracting keratin from duck [42] and turkey feathers [39] when treated at $100-180^{\circ} \mathrm{C}$ for several hours. [BMIM] Cl was also used to prepare wool keratin/cellulose composite materials which displayed a homogeneous structure without any residual fibers [42].

As keratin sources, human hair, feathers and wool have mostly been investigated. Recently, cashmere and camel hair were also suggested as keratin sources [47]. In this work, camel hair and cashmere selected and proposed as new keratin sources were sourced from the Mongolian Camel (with two humps) and Mongolian Goat respectively. The dissolution of camel hair and cashmere in [BMIM]Cl were investigated. Dissolution conditions (temperature, duration and hair/IL ratio) were determined and the physicochemical properties of insoluble and soluble components were analyzed. Moreover, preliminary biological assays were conducted on the freeze-dried soluble part using an in vitro lactate dehydrogenase (LDH) assay and scratch test in murine embryo fibroblast (NIH 3T3) cell cultures.

\section{Materials and methods}

\subsection{Materials}

Camel hair and cashmere were kindly provided by the Mongolian University of Science and Technology. The samples were taken from Mongolian Camel (Bactrian camel, Khaniin Brown Sub-Breed) and Mongolian Goat (Mongol Goat Breed), from the region of Bayankhongor (South-West province of Mongolia). A pre-washing procedure was performed by TUYA Co. Ltd following a standard protocol. Analytical grade1-butyl-3-methylimidazolium chloride ([BMIM]Cl), silicone oil, $6.0 \mathrm{~mol} / \mathrm{L}$ hydrochloric acid standard solution ( $\mathrm{HCl})$, HPLC grade acetonitrile, low/high molecular weight gel filtration calibration kit, lactate dehydrogenase (LDH) activity assay kit and Triton ${ }^{\mathrm{TM}} \mathrm{X}-100$ were purchased from Sigma-Aldrich, St. Louis, USA. Micro BCA ${ }^{\mathrm{TM}}$ protein assay kit, fetal bovine serum (FBS), sodium pyruvate, 1-glutamine and antibiotic/antimycotic were purchased from ThermoFisher Scientific ${ }^{\mathrm{TM}}$, Rockford, USA. Dulbecco's modified Eagle's medium (DMEM), and phosphate buffer saline solution (PBS) were purchased from Euroclone, Pero, Italy. Waters AccQ-Fluor ${ }^{\mathrm{TM}}$ reagent kit and Waters amino acid hydrolysate standards were purchased from Waters Corp., Milford, USA.

\subsection{Dissolution of hairs}

The dissolution procedure and sample codes are summarized in Figure 1. Camel hair (CA_H) and cashmere (CS_H) were cut into small pieces, and immersed in [BMIM] Cl at different weight/weight ratio $(10,15$, and $20 \%, \mathrm{w} / \mathrm{w})$ and kept stirred at $130^{\circ} \mathrm{C}$ for about 10 hours. Soluble and insoluble parts of the keratin were separated by filtration through qualitative filter paper (Grade 1, Waterman ${ }^{\mathrm{TM}}$, SigmaAldrich, Maidstone, England). In order to remove the IL, dialysis was performed on dissolved part against 


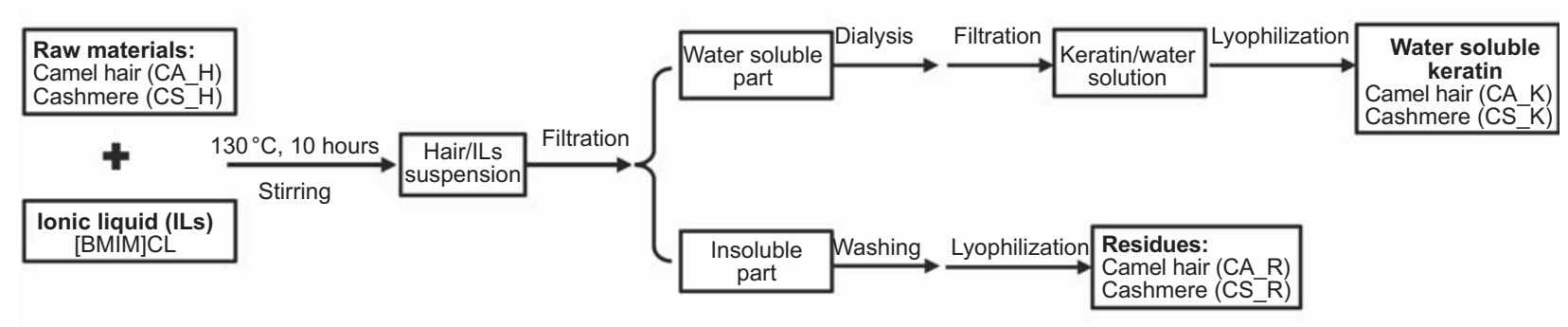

Figure 1. Scheme of processing steps and codes of obtained samples.

distilled water (DI water) using Slide-A-Lyzer Dialysis Cassettes (3500 MWCO, ThermoFisher Scientific $^{\mathrm{TM}}$, Rockford, USA) for 3 days. The insoluble part was washed and centrifuged (20 min, $1000 \mathrm{rpm}$ ) three times with DI water ( $30 \mathrm{ml}$ each time). Finally, the keratin water solution and suspensions were lyophilized (5Pascal, Milan, Italy). Samples obtained from camel hair and cashmere are herewith referred to as CA and CS respectively. The letter $\mathrm{K}$ and $\mathrm{R}$ are used to indicate the soluble $(\mathrm{K})$ and insoluble $(\mathrm{R})$ parts. For example, CA_K refers to materials obtained by freeze-drying the soluble part of keratin from camel hair. All the samples were prepared by mixing three different batches of IL mixtures to average the results.

\subsection{Samples characterization}

\subsubsection{Field emission scanning electron microscopy (FE-SEM)}

Single camel hair (CA_H) and cashmere (CS_H) were sputter coated with $\mathrm{Pt} / \mathrm{Pd}$ and observed with field emission scanning electron microscope (Zeiss Axiotech 100 and Zeiss Supra 40, Germany).

\subsubsection{Fourier transform infrared spectroscopy (FTIR)}

Fourier transform infrared spectroscopy (FTIR) analysis was performed on CA_H and CS_H, CA_K and CS_K, CA_R and CS_R samples. For each measurement, the spectrum was collected in the range $650-4000 \mathrm{~cm}^{-1}$ with 64 scans at a resolution of $4 \mathrm{~cm}^{-1}$. The spectra were baseline corrected, smoothed with the Savitsky-Golay method (10 points). The peaks in the Amide I region (1600-1700 $\mathrm{cm}^{-1}$ were determined using a second order derivative and fitted using a Gaussian function to minimize the $\chi^{2}$ fitting parameter. The peaks were assigned to different protein structures in proportion to the areas of the corresponding peaks $[48,49]$. The spectral processing was performed with Origin 2016 software.

\subsubsection{Thermal analysis}

Thermal analysis of all samples (CA_H and CS_H, CA_K and CS_K, CA_R and CS_R samples) was conducted with a Differential Scanning Calorimeter (DSC, Q20, TA Instrument, USA), in a nitrogen atmosphere with a heating rate of $10^{\circ} \mathrm{C} / \mathrm{min}$ using closed aluminum pans $(3.00-4.00 \mathrm{mg}$ for each sample), at a temperature range $0-330^{\circ} \mathrm{C}$.

\subsubsection{Protein content measurement}

For both soluble and insoluble keratin, the protein content was evaluated by dissolving $4.0 \mathrm{mg}$ in $1.0 \mathrm{ml}$ DI water using a Micro $\mathrm{BCA}^{\mathrm{TM}}$ protein assay kit.

\subsubsection{Amino acid composition analysis}

The amino acid composition of all materials was determined with the Waters AccQ-Fluor ${ }^{\mathrm{TM}}$ reagent kit by the AccQ-TagTM amino acid analysis method (Waters Corp., Milford, USA). For each sample, $4.00 \mathrm{mg}$ was hydrolyzed by $6.0 \mathrm{~mol} / 1 \mathrm{HCl}$ at $120 \pm 2{ }^{\circ} \mathrm{C}$ in a silicone oil bath for $24 \mathrm{~h}$. The air-dried hydrolysates were reconstituted with $20 \mathrm{mM} \mathrm{HCl}$ and then mixed with Water AccQ-Fluor reagent to obtain stable amino acids. The amino acid composition was determined by reverse phase high performance liquid chromatography (RP-HPLC) with an AccQ-TagTM column $(3.9 \times 50 \mathrm{~mm}$, Waters Corp., Milford, MA, USA). A gradient of Waters AccQ-Tag ${ }^{\mathrm{TM}}$ Eluent A, Milli-Q water, and acetonitrile (HPLC grade) was used as solvent. The amino acids were detected using a Jasco UV-1570 detector (Jasco, Bouguenais, France) at $254 \mathrm{~nm}$ and $37.0 \pm 0.5^{\circ} \mathrm{C}$. The chromatograms obtained were compared with Waters amino acid hydrolysate standards. The compositions of amino acids were calculated as molar percentages ( $\mathrm{mol} \%)$.

\subsubsection{Molecular weight}

The molecular weight of soluble keratin from camel (CA_K) and cashmere (CS_K) hair was determined by gel filtration chromatography (GFC). The GFC 
analysis was conducted with a Shodex SB-805 HQ column (Shodex OH pak ${ }^{\circledR}, 8.0 \mathrm{~mm} \times 300 \mathrm{~mm}$, Showa Denko, Munich, Germany). Keratin powder after freeze-drying was redissolved in PBS solution to reach a concentration in the range of $0.5-0.8 \mathrm{mg} / \mathrm{ml}$. The chromatography was operated at a flow rate of $1 \mathrm{ml} / \mathrm{min}$ at $27 \pm 1^{\circ} \mathrm{C}$ using a Jasco UV-1570 detector (Jasco, Bouguenais, France) at $224 \mathrm{~nm}$. The calibration curve was obtained with low/high molecular weight gel filtration calibration kit.

\subsection{Biological evaluation}

\subsubsection{Preparation of keratin/medium solution}

$1.0 \mathrm{mg} / \mathrm{ml} \mathrm{keratin/medium} \mathrm{solution} \mathrm{was} \mathrm{prepared} \mathrm{by}$ dissolving keratin from camel hair (CA_K) and cashmere (CS_K) into standard NIH 3T3 medium. The solutions were filtered through a $0.22 \mu \mathrm{m}$ filter (Euro Clone, Milan, Italy) for sterilization.

\subsubsection{Cell culture}

Murine embryo fibroblast (NIH 3T3, ATCC number: CRL-1658) cell line was cultured in Dulbecco's modified Eagle's medium (DMEM), with 10\% fetal bovine serum (FBS), $1 \mathrm{mM}$ sodium pyruvate, $2 \mathrm{mM}$ 1-glutamine and $1 \%$ antibiotic/antimycotic in a humidified atmosphere of $5 \% \mathrm{CO}_{2}$ at $37^{\circ} \mathrm{C}$, changing the medium every third day. Cells (at passage number 8 ) were collected by trypsin and were seeded in a 96-well plate $\left(3 \cdot 10^{3}\right.$ cells/well in $0.2 \mathrm{ml}$ medium $)$ for lactate dehydrogenase activity assay (LDH assay) and a 6well plate $\left(1 \cdot 10^{5}\right.$ cells/well in $2 \mathrm{ml}$ medium $)$ for scratch test, and cultured in standard NIH 3 T3 medium.

\subsubsection{Cytotoxicity assay}

The cytotoxicity of camel hair (CA_K) and cashmere (CS_K) soluble keratin was evaluated by using the LDH assay on NIH 3 T3 cell lines in vitro cultures at $37^{\circ} \mathrm{C}$, replacing the cell culture medium with the above reported keratin/medium solution when the confluence reached $70 \%$. The LDH released by cells in culture supernatants was measured at day 1 and day 2 . Fully lysed cells (by adding $0.05 \%$ Triton $^{\mathrm{TM}} \mathrm{X}-100$ ), cells cultured in standard medium without soluble keratin were used as positive and negative control, respectively. Samples and controls were in quintuplicate for each time point.

\subsubsection{Scratch test}

Once the cell confluence reached $70 \%$, a linear scratch was made in the cell monolayer using a sterile $100 \mu \mathrm{l}$ plastic pipette tip. $2 \mathrm{ml}$ PBS per well was added to wash the cellular debris. The PBS was removed and $2 \mathrm{ml}$ of keratin/medium solution $(1.0 \mathrm{mg} / \mathrm{ml})$ and standard NIH 3T3 medium (control group) were added. Photographs were taken by a microscope equipped with an automatic stage (Nikon Ti, Nikon, Japan) on day 0 and day 1 . The images were post-processed by software (GIMP 2) to calculate the decreasing ratio of blank area for samples and controls. For each time point, samples and controls were in triplicate and three points were selected to image each scratch.

\subsection{Statistical analysis}

Statistical evaluation was carried out using Origin Pro 2016 and Microsoft Office Excel 2010. Data were expressed as mean \pm standard deviation (SD). One-way ANOVA with the Bonferroni correction $\left({ }^{*} p<0.05 ;{ }^{* *} p<0.01 ; * * * p<0.001 ; * * * * p<0.0001\right)$ was utilized to evaluate the biological tests using GraphPad Prism 5.

\section{Results and discussion}

\subsection{Dissolution of camel hair and cashmere in ionic liquid}

In order to test dissolution, 10, 15 and $20 \%(\mathrm{w} / \mathrm{w})$ of CA_H and CS_H in IL were initially investigated, with a marked increase in the viscosity of the resulting suspensions and correspondingly, a decrease in the dissolution rate with increasing keratin [41]. 15\% (w/w) was set as the working concentration, corresponding to the reported solubility of wool in [BMIM] Cl [17, 41]. In both IL mixtures, CA_H and CS_H did not dissolve completely, and a net phase separation between soluble and insoluble fractions was observed. At the end of the dissolution/washing procedure, $20 \pm 4 \%(\mathrm{w} / \mathrm{w}$ ) of the original hair sample was evaluated to be in solution, $40 \pm 5 \%(\mathrm{w} / \mathrm{w})$ formed the insoluble part, and the remaining $40 \pm 9 \%(\mathrm{w} / \mathrm{w})$ was lost in the process. To the best of our knowledge, no comparative data on the yield of keratin isolated with the same method from camel hair or cashmere has been reported to date. Values of the yield of keratin from wool by using [BMIM] Cl have been previously 
reported, with results ranging from 18 to $57 \%(\mathrm{w} / \mathrm{w})$ with a dependence on the dissolution temperature [50].

\subsection{Characterization of keratin from camel hairs and cashmere}

Morphological observation of camel hair (CA_H) and cashmere (CS H) by FE-SEM was performed to compare the structure of raw materials (Figure 2). While the overall morphologies are similar, cashmere (Figure 2b) fibers are thinner with thicker cuticle scale edges in comparison to the camel hair fiber.

The molecular structure of the soluble and insoluble keratin fractions after freeze-drying was characterized by FTIR spectroscopy (Figure 3). The peaks center around $3280 \mathrm{~cm}^{-1}$ (Amide A) present in all materials are characteristic of $\mathrm{N}-\mathrm{H}$ stretching. The range of $1650-1630 \mathrm{~cm}^{-1}$, associate to Amide $\mathrm{I}$, is usually attributed to $\mathrm{C}=\mathrm{O}$ bending. The Amide II vibrations show a strong absorption band in the range of $1530-1517 \mathrm{~cm}^{-1}$ attributed to $\mathrm{C}-\mathrm{N}$ stretching and $\mathrm{N}-\mathrm{H}$ bending vibrations. A weak absorption band can be found in the $1273-1230 \mathrm{~cm}^{-1}$ range. This band, associated to Amide III, is due to the $\mathrm{C}-\mathrm{N}, \mathrm{C}-\mathrm{O}$ stretching, $\mathrm{N}-\mathrm{H}$, and $\mathrm{O}=\mathrm{C}-\mathrm{N}$ bending vibrations. Is worth noting that all these peaks were previously found in feather [40] and wool [25] keratin, and are associated to the common peaks found in fibrous proteins [51].

Some differences may be observed comparing original hair ( $\mathrm{CA} \mathrm{H}$ and $\mathrm{CS} \mathrm{H}$ ), soluble keratin (CA K and CS_K) and insoluble residues (CA_R and CS_R). Comparing pristine hair and soluble keratin, in the region of Amide I, curves presented a slight shift from $1630 \mathrm{~cm}^{-1}$ (CA_H and CS_H) to $1650 \mathrm{~cm}^{-1}$

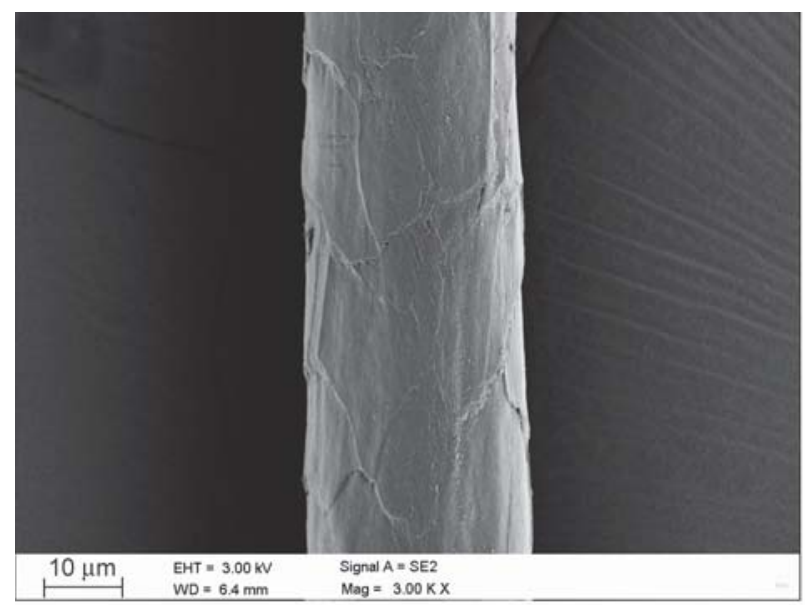

a)

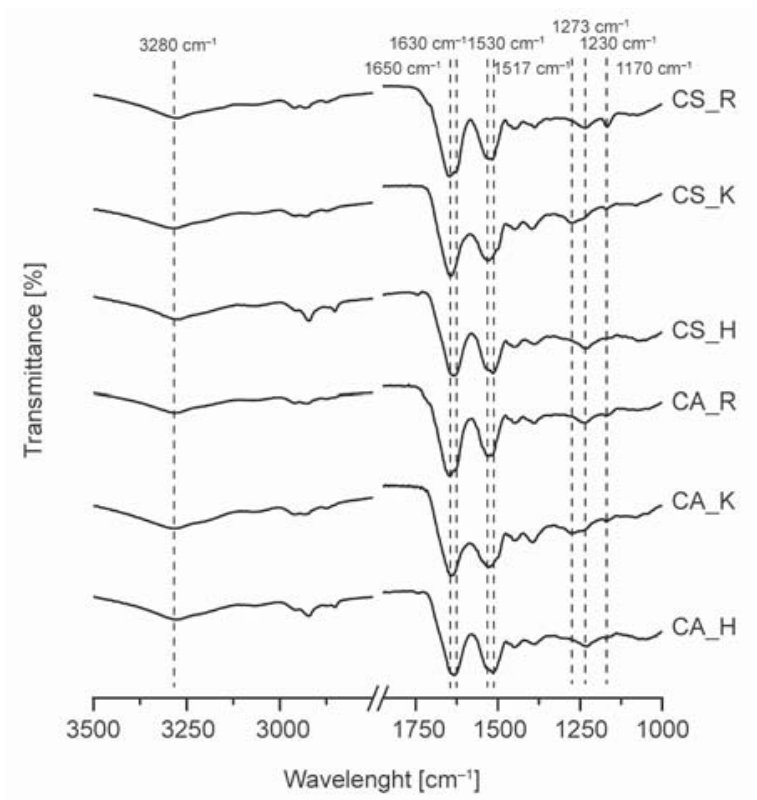

Figure 3. FTIR spectra of samples. CA_H: camel hair, CA_K: soluble camel hair keratin, CA_R: camel hair residue, CS_H: cashmere, CS_K: soluble cashmere keratin, CS R: cashmere residue.

(CA_K and CS_K). This indicates a partial conformational transition from $\beta$-sheet to $\alpha$-helix $[45,52]$. The same $\alpha$-helix and $\beta$-sheet peaks were found in both residues (CA_R and CS R). A small peak centered on $1170 \mathrm{~cm}^{-1}$, detected only in the soluble keratin (CA_K and CS_K) and residues (CA_R and CS_R), can be assigned to the asymmetric $\mathrm{S}-\mathrm{O}$ bond. The formation of the $\mathrm{S}-\mathrm{O}$ bond indicates the partial oxidation of the disulfide bonds during the dissolution of the hair in IL [45]. In order to better elucidate the structure of the protein in different samples, a detailed secondary structure analysis was performed by analyzing the Amide I region $\left(1600-1700 \mathrm{~cm}^{-1}\right)$. The peak centered around $1662-1653 \mathrm{~cm}^{-1}$ suggests the

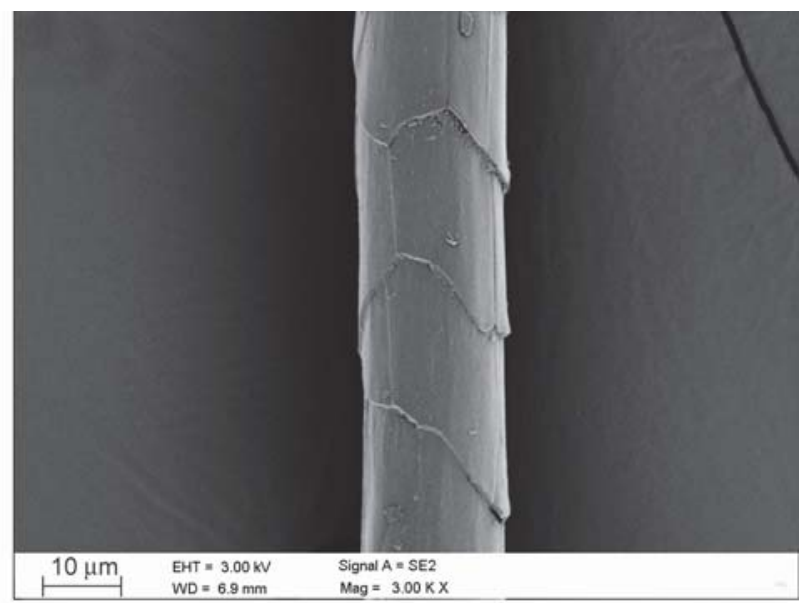

b)

Figure 2. FE-SEM images of a Mongolian camel hair (a) and a Mongolian goat cashmere (b). 

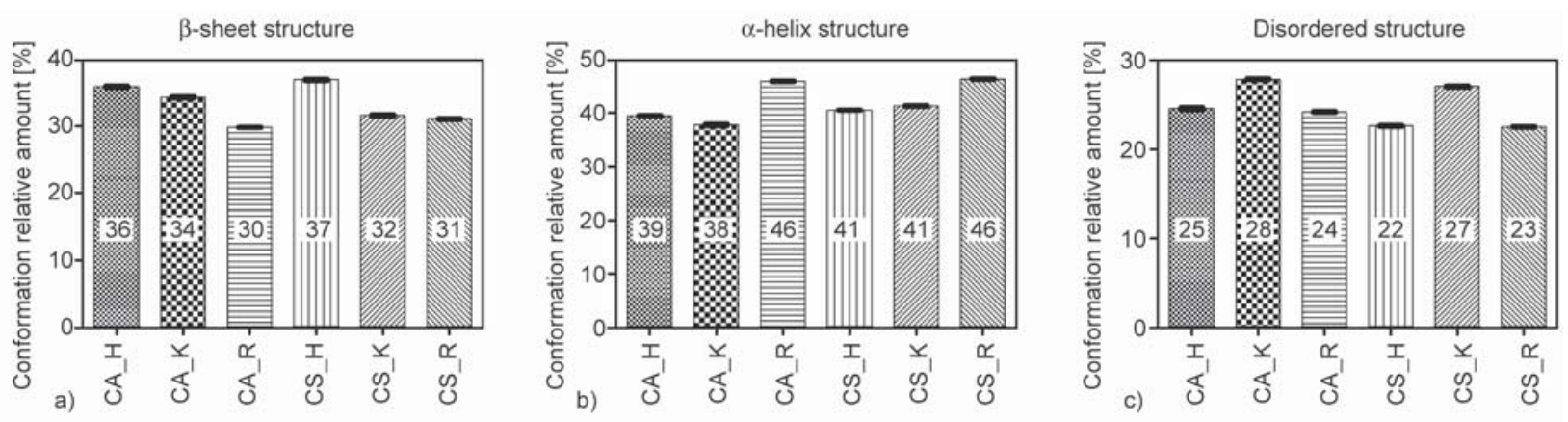

Figure 4. Relative amount of $\beta$-sheet (a), $\alpha$-helix (b) and disordered structure (c), SD $<0.1 \%, p<0.001$ (one-way ANOVA with the Bonferroni correction). CA_H: camel hair, CA_K: soluble camel hair keratin, CA_R: camel hair residue, CS_H: cashmere, CS_K: soluble cashmere keratin, CS_R: cashmere residue.

presence of $\alpha$-helix; the peak in the region of 1637 $1616 \mathrm{~cm}^{-1}$ reveals the presence of $\beta$-sheet; finally low intensity peaks at $1696-1663$ and $1652-1638 \mathrm{~cm}^{-1}$ indicate disordered keratin conformations [53, 54]. Even though no significant differences can be detected between the different samples (Figure 4), less $\beta$ sheet and more $\alpha$-helix can be detected in soluble keratin (CA_K and CS_K) and residual (CA_R and CS_R) materials, in comparison to the starting hair samples (CA_H and CS_H). In particular, presence in residues (CA_R and CS_R) of about $30 \%$ of $\beta$ sheet and $46 \%$ of $\alpha$-helix indicates that structure of camel and cashmere hair have disassembled structures, resulting in a more disordered structure in soluble keratin powder and an increase of $\alpha$-helix in residues.

DSC curves of all the samples are presented in Figure 5. In all curves, the first wide peak centered

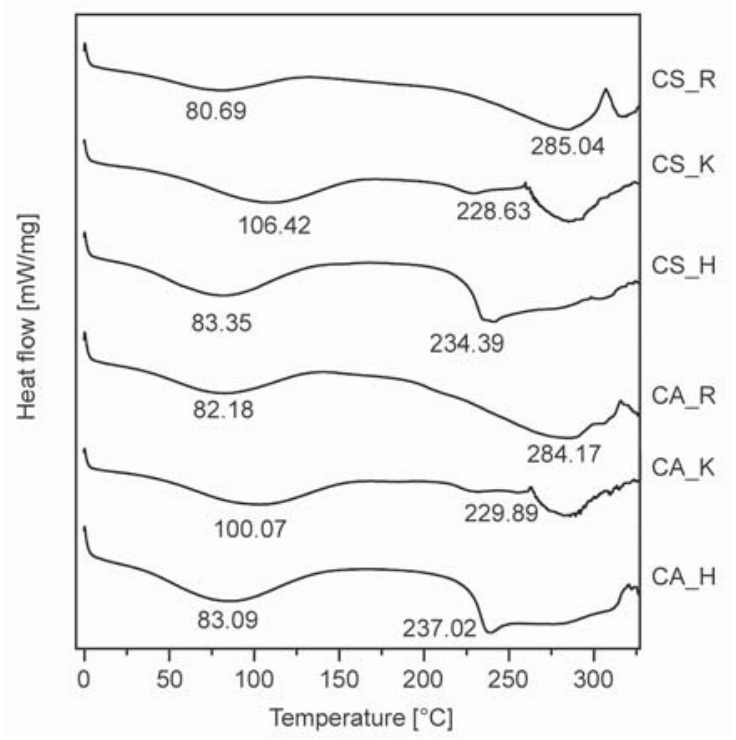

Figure 5. DSC curves of samples. CA_H: camel hair, CA_K: soluble camel hair keratin, CA_R: camel hair residue, CS_H: cashmere, CS_K : soluble cashmere keratin, CS_R: cashmere residue. around 80 to $110^{\circ} \mathrm{C}$ is related to water evaporation [55]. For hair (CA_H and CS_H) and water soluble keratin (CA_K and CS_K), the second peak centered at $230-250{ }^{\circ} \mathrm{C}$ is generally attributed to $\alpha$-helix disordering and decomposition [56]. For the residues (CA_R and CS_R), no obvious peak can be detected around $230^{\circ} \mathrm{C}$. Instead, the peaks at $273^{\circ} \mathrm{C}$ (CA_R) and $288^{\circ} \mathrm{C}\left(\mathrm{CS} \_\mathrm{R}\right)$ can be attributed to protein degradation. A slight shift of $\alpha$-helix denaturation to lower temperature is also observed in the keratin powder, compared with both camel hair and cashmere. This suggests the formation of a greater degree of disordered phase and decrease of $\alpha$-helix, which matches the secondary structure analysis [39].

The results of protein concentration measured by BCA showed that the soluble keratin part did not contain only keratin, which was evaluated to be about $91 \%(\mathrm{w} / \mathrm{v})$ of the total for CA_K and about 98\% for CS_K. As reported, keratin can provide specific adhesion moieties for cells due to recognizable adhesion sequences in its structure. In addition to the RGD (Arginine-Glycine-Aspartic acid) motifs, XAspartic Acid-Y motifs (where X equals to glycine, leucine, or glutamic acid and $\mathrm{Y}$ equals to serine or valine) are known cell adhesion sequences in keratin [57]. As reported in Table 1 (data from wool keratin [48], human hair keratin [58]), around $60 \%$ of amino acids of the water soluble keratin (CA_K and CS_K) are present in the above adhesion sequences. Proteins with a high content of cysteine (Cys) are difficult to dissolve due to the stability of the disulfide bond [59]. In our case, Cys is present in the original hair samples, at different percentages depending on the source (e.g. $7.9 \mathrm{~mol} \%$ in CA $\mathrm{H}$ and $6.3 \mathrm{~mol} \%$ in CS_H). After dissolution, the content of Cys sharply decreases for both materials, and is no longer detectable in CA_K, while only $0.4 \mathrm{~mol} \%$ in CS_K. Molecular weight measurements of soluble keratin 
Table 1. Amino acid composition of samples $(\mathrm{SD}<0.1 \%)$.

\begin{tabular}{|c|c|c|c|c|c|c|c|c|}
\hline $\begin{array}{l}\text { Mol } \\
{[\%]}\end{array}$ & CA_H & CA_K & CA_R & CS_H & CS_K & CS_R & Wool keratin & Human hair keratin \\
\hline Cys & 7.9 & 0.0 & 0.8 & 6.3 & 0.4 & 1.9 & 10.4 & 12.9 \\
\hline Arg & 8.1 & 10.1 & 9.4 & 8.1 & 8.5 & 8.2 & 6.6 & 3.2 \\
\hline Gly & 7.8 & 9.1 & 8.1 & 9.4 & 9.5 & 8.3 & 8.2 & 6.7 \\
\hline Asp & 10.4 & 6.1 & 6.6 & 4.9 & 9.1 & 7.2 & 8.5 & 7.1 \\
\hline Leu & 8.1 & 11.7 & 11.9 & 9.4 & 8.5 & 10.4 & 7.0 & 8.0 \\
\hline Val & 6.8 & 8.5 & 8.7 & 7.3 & 7.1 & 7.5 & 5.3 & 6.9 \\
\hline Glu & 11.3 & 8.6 & 10.5 & 7.4 & 13.8 & 14.6 & 13.3 & 12.8 \\
\hline Ser & 8.5 & 5.9 & 6.7 & 8.1 & 9.5 & 8.2 & 10.3 & 12.2 \\
\hline Ala & 6.2 & 10.4 & 9.5 & 8.5 & 6.8 & 6.8 & 5.1 & 4.7 \\
\hline Ile & 3.4 & 5.2 & 4.6 & 4.1 & 3.8 & 4.2 & 2.9 & 3.6 \\
\hline Thr & 5.9 & 5.1 & 5.7 & 6.4 & 5.8 & 5.6 & 6.8 & 19.6 \\
\hline Met & 0.4 & 0.5 & 0.5 & 0.3 & 0.4 & 0.5 & 0.3 & 0.8 \\
\hline Lys & 3.1 & 3.4 & 3.8 & 3.5 & 3.0 & 3.6 & 2.7 & 2.6 \\
\hline His & 0.7 & 1.0 & 0.9 & 0.7 & 0.7 & 0.8 & 0.7 & 1.1 \\
\hline Phe & 2.5 & 4.6 & 4.4 & 4.1 & 2.7 & 4.0 & 2.2 & 2.2 \\
\hline Tyr & 2.1 & 3.0 & 2.4 & 3.5 & 3.8 & 2.9 & 3.4 & 1.4 \\
\hline Pro & 6.9 & 7.0 & 5.6 & 8.2 & 6.9 & 5.6 & 6.1 & 7.1 \\
\hline
\end{tabular}

CA_H: camel hair, CA_K: water soluble camel hair keratin, CA_R: camel hair residue, CS_H: cashmere, CS_K: water soluble cashmere keratin, CS_R: cashmere residue.

from camel hair (CA_K) and cashmere (CS_K) determined by GFC did not noticeably differ between CA_K (34.6 kDa, PDI 5.65) and CS_K (32.5 kDa, PDI 4.60). It may be noted that these values do not compare with the SDS-PAGE analysis of Tonin et al. [60], who used a different dissolution method on wool. They reported finding low sulfur $(67-43 \mathrm{kDa})$ and high sulfur containing protein chains (28$11 \mathrm{kDa}$ ). Our results suggest instead, that ILs may cleave the protein into smaller polypeptide chains.

\subsection{Preliminary biological evaluation}

Cytotoxicity of water soluble keratin fractions (CA_K and CS_K) was evaluated in vitro. The results of the LDH assay (Figure 6) demonstrated that soluble keratin from camel and cashmere hair is not cytotoxic (1.0 mg of sample/ $1 \mathrm{ml}$ of cell culture medium) during 2 days of culture, with results similar to the control sample. The scratch test is a well-defined method to evaluate directional cell migration in vitro and in a wound healing model [61]. This test was performed on NIH 3 T3 cell culture using medium enriched with soluble camel hair (CA_K) and cashmere keratin (CS_K). After cells reached confluence, an artificial gap (scratch) was created on all samples and images were taken at the beginning and after 24 hours (Figure 7) to monitor cell migration. Figure 8 compares the areas of the scratch after 24 hours to its initial value, for standard medium and $1.0 \mathrm{mg} / \mathrm{ml}$ enriched

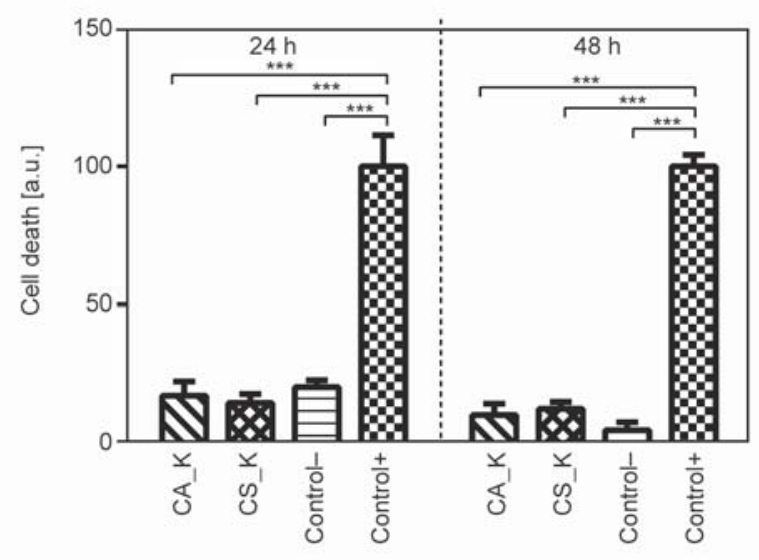

One-way ANOVA with the Bonferroni correction ${ }^{\star} p<0.05 ;{ }^{* \star} p<0.01 ;{ }^{* \star *} p<0.001 ;{ }^{* \star * \star} p<0.0001$

Figure 6. Results of LDH assay of water soluble keratin. CA_K: water soluble camel hair keratin, CS_K: water soluble cashmere keratin, Control-: negative control was represented by cells cultured in standard medium without soluble keratin, Control+: positive control for cytotoxicity was represented by fully lysate cells (Triton $\left.{ }^{\mathrm{TM}} \mathrm{X}-100\right)$.

medium cell cultures. The presence of keratin in the medium clearly increases the directional migration of fibroblasts in the scratched monolayer with respect to the control with an absence of keratin medium. In general, the source can affect the final quality and bioactivity of the isolated products. Here, higher cell bioactivity is observed when the cells are cultured in the presence of CA_K and CS_K compared with the control group. Although this test is not a 


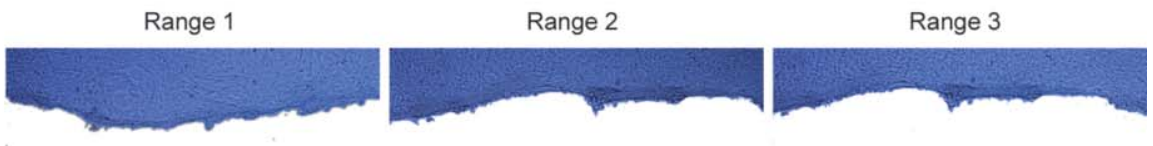

CA-K $K$
day 0

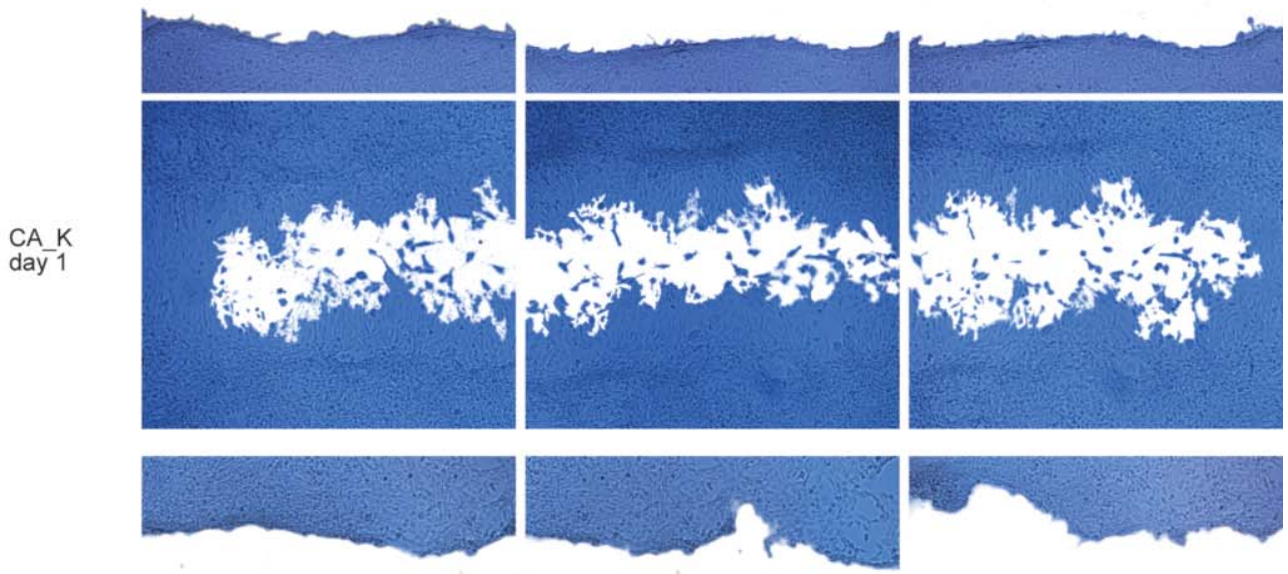

day

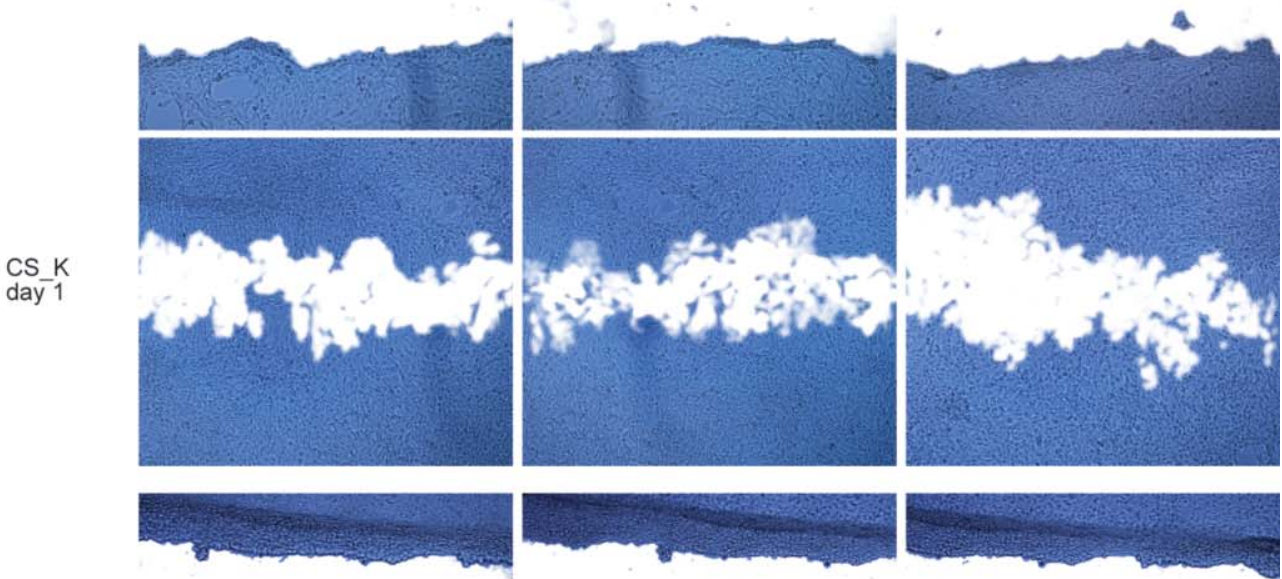

Control

day 0

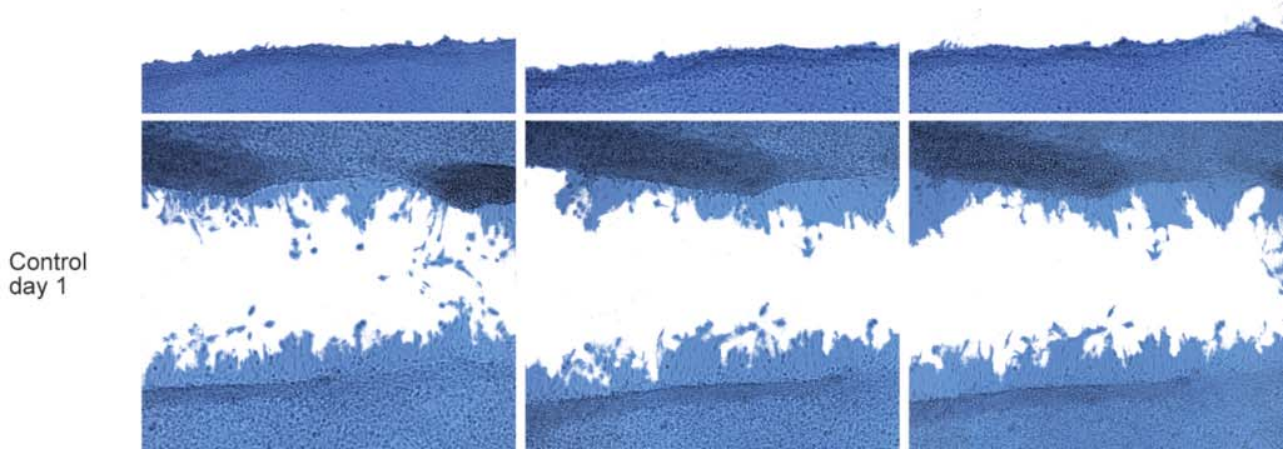

Figure 7. Scratch assay images in day 0 and day 1.CA_K: water soluble camel hair keratin, CS_K: water soluble cashmere keratin.

conclusive proof for efficacy in tissue healing [62, 63], it provides a well-established method to evaluate cell migration ability.

\section{Conclusions}

Keratin composition, structure and bioactivity are different depending on the source. In this study, 

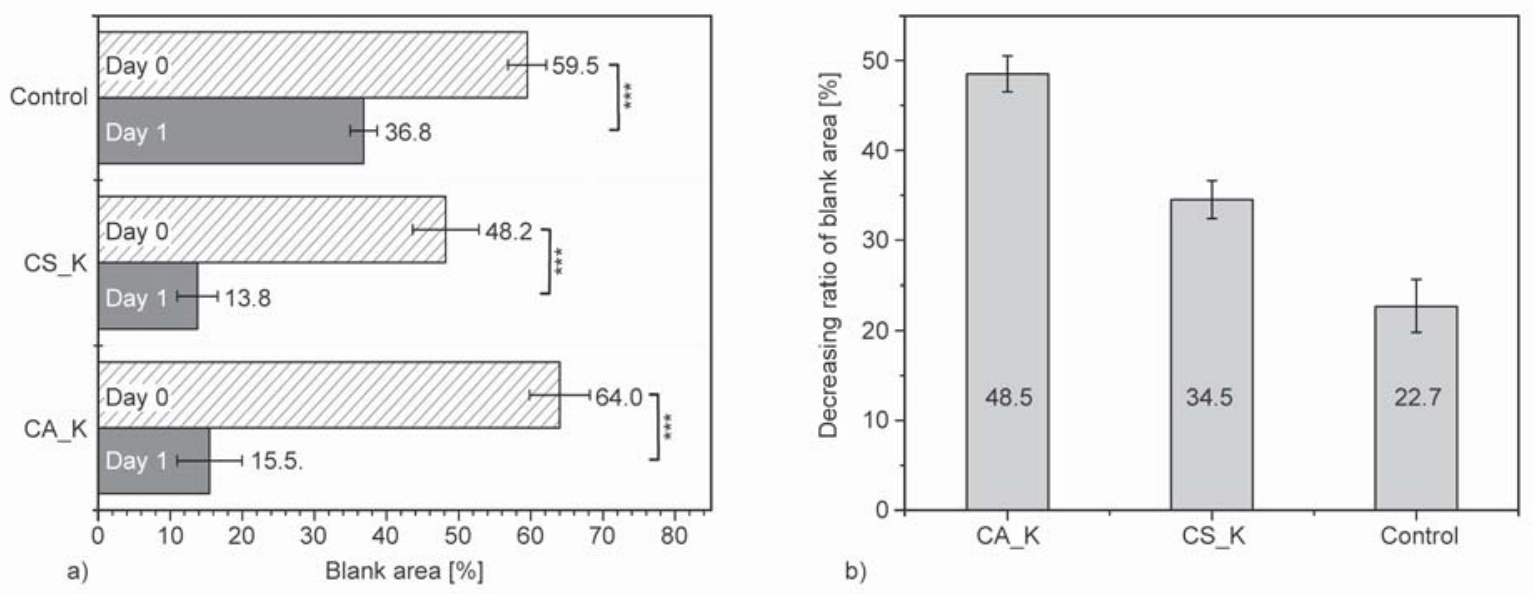

Figure 8. Comparison of blank area (a) and decreasing ratio (b) of samples and control. CA_K: water soluble camel hair keratin, CS_K: water soluble cashmere keratin, Control: standard NIH 3 T3 medium. (One-way ANOVA with the Bonferroni correction, $\left.{ }^{*} p<0.05 ; * * p<0.01 ; * * p<0.001 ; * * * *<0.0001\right)$.

camel hair and cashmere were investigated as novel potential sources of keratin. These natural sources were dissolved with $[\mathrm{BMIM}] \mathrm{Cl}$ to generate water soluble keratin fractions. In particular, it was found that both camel hairs and cashmere are partly soluble in [BMIM] $\mathrm{Cl}$ at $130^{\circ} \mathrm{C}$. For the first time, it is possible to separate soluble keratin powder and insoluble residues, with a yield of water soluble keratin at $20 \pm 4 \%(\mathrm{w} / \mathrm{w})$ in both raw materials. The morphological differences between camel hair and cashmere were distinguished by FE-SEM. Considering the soluble keratin obtained, secondary structure (FTIR), thermal behavior (DSC), amino acid composition and molecular weight analysis showed no significant differences. For the protein structure, secondary structure analysis showed a slight decrease in $\beta$-sheet and $\alpha$-helix, but a visible increase in disordered structure. Expectedly, the percentage of each conformation is different depending on the sources. In general, the amino acid composition of Cys is very low after the dissolution process. The use of IL in the dissolution process does not induce any cytotoxicity effect on cells. A scratch test showed a higher migration activity in cells cultured in the presence of both keratins. Although the performed biological tests are preliminary, regenerated keratin from camel hair and cashmere can be considered as promising candidates for the design of tissue engineering matrices.

\section{Acknowledgements}

This research has been supported by REMIX, funded by the European Union's Horizon 2020 research and innovation programme under the Maria Sklodowska-Curie grant agreement n. 778078 .

\section{References}

[1] Eslahi N., Dadashian F., Nejad N. H.: An investigation on keratin extraction from wool and feather waste by enzymatic hydrolysis. Preparative Biochemistry and Biotechnology, 43, 624-648 (2013). https://doi.org/10.1080/10826068.2013.763826

[2] Reddy N., Yang Y.: Structure and properties of chicken feather barbs as natural protein fibers. Journal of Polymers and the Environment, 15, 81-87 (2007). https://doi.org/10.1007/s10924-007-0054-7

[3] Bohacz J.: Biodegradation of feather waste keratin by a keratinolytic soil fungus of the genus Chrysosporium and statistical optimization of feather mass loss. World Journal of Microbiology and Biotechnology, 33, 13/113/16 (2017). https://doi.org/10.1007/s11274-016-2177-2

[4] Alibardi L.: Ultrastructural localization of hair keratins, high sulfur keratin-associated proteins and sulfhydryl oxidase in the human hair. Anatomical Science International, 92, 248-261 (2017). https://doi.org/10.1007/s12565-016-0330-5

[5] Rechiche O., Plowman J. E., Harland D. P., Lee T. V., Lott J. S.: Expression and purification of high sulfur and high glycine-tyrosine keratin-associated proteins (KAPs) for biochemical and biophysical characterization. Protein Expression and Purification, 146, 34- 44 (2018). https://doi.org/10.1016/j.pep.2017.12.006

[6] Cilurzo F., Selmin F., Aluigi A., Bellosta S.: Regenerated keratin proteins as potential biomaterial for drug delivery. Polymers for Advanced Technologies, 24, 10251028 (2013). https://doi.org/10.1002/pat.3168

[7] Esparza Y., Ullah A., Wu J.: Molecular mechanism and characterization of self-assembly of feather keratin gelation. International Journal of Biological Macromolecules, 107, 290-296 (2018).

https://doi.org/10.1016/j.ijbiomac.2017.08.168 
[8] Wang K., Li R., Ma J. H., Jian Y. K., Che J. N.: Extracting keratin from wool by using L-cysteine. Green Chemistry, 18, 476-481 (2016).

https://doi.org/10.1039/c5gc01254f

[9] Nam K., Kimura T., Kishida A.: Preparation and characterization of cross-linked collagen-phospholipid polymer hybrid gels. Biomaterials, 28, 1-8 (2007). https://doi.org/10.1016/j.biomaterials.2006.08.002

[10] Stenzel K. H., Miyata T., Rubin A. L.: Collagen as a biomaterial. Annual Review of Biophysics and Bioengineering, 3, 231-253 (1974). https://doi.org/10.1146/annurev.bb.03.060174.001311

[11] Ko J., Nguyen L. T., Surendran A., Tan B. Y., Ng K. W., Leong W. L.: Human hair keratin for biocompatible flexible and transient electronic devices. ACS Applied Materials and Interfaces, 9, 43004-43012 (2017). https://doi.org/10.1021/acsami.7b16330

[12] Xu H., Cai S., Xu L., Yang Y.: Water-stable three-dimensional ultrafine fibrous scaffolds from keratin for cartilage tissue engineering. Langmuir, 30, 8461-8470 (2014). https://doi.org/10.1021/la500768b

[13] Borrelli M., Joepen N., Reichl S., Finis D., Schoppe M., Geerling G., Schrader S.: Keratin films for ocular surface reconstruction: Evaluation of biocompatibility in an in-vivo model. Biomaterials, 42, 112-120 (2015). https://doi.org/10.1016/j.biomaterials.2014.11.038

[14] Han S., Ham T. R., Haque S., Sparks J. L., Saul J. M.: Alkylation of human hair keratin for tunable hydrogel erosion and drug delivery in tissue engineering applications. Acta Biomaterialia, 23, 201-213 (2015). https://doi.org/10.1016/j.actbio.2015.05.013

[15] Nakata R., Osumi Y., Miyagawa S., Tachibana A., Tanabe T.: Preparation of keratin and chemically modified keratin hydrogels and their evaluation as cell substrate with drug releasing ability. Journal of Bioscience and Bioengineering, 120, 111-116 (2015).

https://doi.org/10.1016/j.jbiosc.2014.12.005

[16] Shanmugasundaram O., Ahmed K. S. Z., Sujatha K., Ponnmurugan P., Srivastava A., Ramesh R., Sukumar R., Elanithi K.: Fabrication and characterization of chicken feather keratin/polysaccharides blended polymer coated nonwoven dressing materials for wound healing applications. Materials Science and Engineering: C, 92, 26 33 (2018).

https://doi.org/10.1016/j.msec.2018.06.020

[17] Shavandi A., Silva T. H., Bekhit A. A., Bekhit A. E-D. A.: Keratin: Dissolution, extraction and biomedical application. Biomaterials Science, 5, 1699-1735 (2017). https://doi.org/10.1039/c7bm00411g

[18] Sonavane P. R., Wang C., Dzamba B., Weber G. F., Periasamy A., DeSimone D. W.: Mechanical and signaling roles for keratin intermediate filaments in the assembly and morphogenesis of Xenopus mesendoderm tissue at gastrulation. Development, 144, 4363-4376 (2017). https://doi.org/10.1242/dev.155200
[19] Wu Y-L., Lin C-W., Cheng N-C., Yang K-C., Yu J.: Modulation of keratin in adhesion, proliferation, adipogenic, and osteogenic differentiation of porcine adipose-derived stem cells. Journal of Biomedical Materials Research Part B: Applied Biomaterials, 105, 180192 (2017). https://doi.org/10.1002/jbm.b.33551

[20] Kakkar P., Madhan B., Shanmugam G.: Extraction and characterization of keratin from bovine hoof: A potential material for biomedical applications. SpringerPlus, 3, 596/1-596/9 (2014). https://doi.org/10.1186/2193-1801-3-596

[21] Ferraris S., Guarino V., Cochis A., Varesano A., Maya I. C., Vineis C., Rimondini L., Spriano S.: Aligned keratin submicrometric-fibers for fibroblasts guidance onto nanogrooved titanium surfaces for transmucosal implants. Materials Letters, 229, 1-4 (2018). https://doi.org/10.1016/j.matlet.2018.06.103

[22] Yen K-C., Chen C-Y., Huang J-Y., Kuo W-T., Lin F-H.: Fabrication of keratin/fibroin membranes by electrospinning for vascular tissue engineering. Journal of Materials Chemistry B, 4, 237-244 (2016). https://doi.org/10.1039/c5tb01921d

[23] Esparza Y., Ullah A., Wu J.: Preparation and characterization of graphite oxide nano-reinforced biocomposites from chicken feather keratin. Journal of Chemical Technology and Biotechnology, 92, 2023-2031 (2017). https://doi.org/10.1002/jctb.5196

[24] Esparza Y., Bandara N., Ullah A., Wu J.: Hydrogels from feather keratin show higher viscoelastic properties and cell proliferation than those from hair and wool keratins. Materials Science and Engineering: C, 90, 446-453 (2018). https://doi.org/10.1016/j.msec.2018.04.067

[25] Silva R., Singh R., Sarker B., Papageorgiou D. G., Juhasz J. A., Roether J. A., Cicha I., Kaschta J., Schubert D. W., Chrissafis K., Detsch R., Boccaccini A. R.: Hybrid hydrogels based on keratin and alginate for tissue engineering. Journal of Materials Chemistry B, 2, 5441-5451 (2014).

https://doi.org/10.1039/c4tb00776j

[26] Ham T. R., Lee R. T., Han S., Haque S., Vodovotz Y., Gu J., Burnett L. R., Tomblyn S., Saul J. M.: Tunable keratin hydrogels for controlled erosion and growth factor delivery. Biomacromolecules, 17, 225-236 (2015). https://doi.org/10.1021/acs.biomac.5b01328

[27] Nakata R., Tachibana A., Tanabe T.: Preparation of keratin hydrogel/hydroxyapatite composite and its evaluation as a controlled drug release carrier. Materials Science and Engineering: C, 41, 59-64 (2014). https://doi.org/10.1016/j.msec.2014.04.016

[28] Xu S., Sang L., Zhang Y., Wang X., Li X.: Biological evaluation of human hair keratin scaffolds for skin wound repair and regeneration. Materials Science and Engineering: C, 33, 648-655 (2013). https://doi.org/10.1016/j.msec.2012.10.011 
[29] Li J-S., Li Y., Liu X., Zhang J., Zhang Y.: Strategy to introduce an hydroxyapatite-keratin nanocomposite into a fibrous membrane for bone tissue engineering. Journal of Materials Chemistry B, 1, 432-437 (2013). https://doi.org/10.1039/c2tb00460g

[30] Yin X-C., Li F-Y., He Y-F., Wang Y., Wang R-M.: Study on effective extraction of chicken feather keratins and their films for controlling drug release. Biomaterials Science, 1, 528-536 (2013). https://doi.org/10.1039/c3bm00158j

[31] Guo J., Pan S., Yin X., He Y-F., Li T., Wang R-M.: pHsensitive keratin-based polymer hydrogel and its controllable drug-release behavior. Journal of Applied Polymer Science, 132, 41572/1-41572/8 (2015). https://doi.org/10.1002/app.41572

[32] Avila Rodríguez M. I., Rodríguez Barroso L. G., Sánchez M. L.: Collagen: A review on its sources and potential cosmetic applications. Journal of Cosmetic Dermatology, 17, 20-26 (2018).

https://doi.org/10.1111/jocd.12450

[33] Wong W. C. V., Narkevicius A., Chow W. Y., Reid D. G., Rajan R., Brooks R. A., Green M., Duer M. J.: Solid state NMR of isotope labelled murine fur: A powerful tool to study atomic level keratin structure and treatment effects. Journal of Biomolecular NMR, 66, 93-98 (2016). https://doi.org/10.1007/s10858-016-0056-7

[34] Wang B., Yang W., McKittrick J., Meyers M. A.: Keratin: Structure, mechanical properties, occurrence in biological organisms, and efforts at bioinspiration. Progress in Materials Science, 76, 229-318 (2016).

https://doi.org/10.1016/j.pmatsci.2015.06.001

[35] Bhavsar P., Zoccola M., Patrucco A., Montarsolo A., Rovero G., Tonin C.: Comparative study on the effects of superheated water and high temperature alkaline hydrolysis on wool keratin. Textile Research Journal, 87, 1696-1705 (2017).

https://doi.org/10.1177/0040517516658512

[36] Dalev P. G.: Utilisation of waste feathers from poultry slaughter for production of a protein concentrate. Bioresource Technology, 48, 265-267 (1994).

https://doi.org/10.1016/0960-8524(94)90156-2

[37] Zhang Y., Zhao W., Yang R.: Steam flash explosion assisted dissolution of keratin from feathers. ACS Sustainable Chemistry and Engineering, 3, 2036-2042 (2015).

https://doi.org/10.1021/acssuschemeng.5b00310

[38] Lee H., Noh K., Lee S. C., Kwon I-K., Han D-W., Lee I-S., Hwang Y-S.: Human hair keratin and its-based biomaterials for biomedical applications. Tissue Engineering and Regenerative Medicine, 11, 255-265 (2014). https://doi.org/10.1007/s13770-014-0029-4

[39] Idris A., Vijayaraghavan R., Rana U. A., Fredericks D., Patti A., MacFarlane D.: Dissolution of feather keratin in ionic liquids. Green Chemistry, 15, 525-534 (2013). https://doi.org/10.1039/C2GC36556A
[40] Idris A., Vijayaraghavan R., Patti A., MacFarlane D.: Distillable protic ionic liquids for keratin dissolution and recovery. ACS Sustainable Chemistry and Engineering, 2, 1888-1894 (2014). https://doi.org/10.1021/sc500229a

[41] Idris A., Vijayaraghavan R., Rana U. A., Patti A., MacFarlane D.: Dissolution and regeneration of wool keratin in ionic liquids. Green Chemistry, 16, 2857-2864 (2014). https://doi.org/10.1039/C4GC00213J

[42] Xie H., Li S., Zhang S.: Ionic liquids as novel solvents for the dissolution and blending of wool keratin fibers. Green Chemistry, 7, 606-608 (2005).

https://doi.org/10.1039/b502547h

[43] Yoo C. G., Pu Y., Ragauskas A. J.: Ionic liquids: Promising green solvents for lignocellulosic biomass utilization. Current Opinion in Green and Sustainable Chemistry, 5, 5-11 (2017). https://doi.org/10.1016/j.cogsc.2017.03.003

[44] Li R., Wang D.: Preparation of regenerated wool keratin films from wool keratin-ionic liquid solutions. Journal of Applied Polymer Science, 127, 2648-2653 (2013). https://doi.org/10.1002/app.37527

[45] Zhao X., Min J., He J., Wang H-L.: Study of dyeing kinetics of wool fabrics treated with microwave (in Chinese). Wool Textile Journal, 38, 1-5 (2010). https://doi.org/10.3969/j.issn.1003-1456.2010.07.001

[46] Marelli B., Omenetto F. G.: Cashmere-derived keratin for device manufacturing on the micro- and nanoscale. Journal of Materials Chemistry C, 3, 2783-2787 (2015). https://doi.org/10.1039/c5tc00056d

[47] Aluigi A., Zoccola M., Vineis C., Tonin C., Ferrero F., Canetti M.: Study on the structure and properties of wool keratin regenerated from formic acid. International Journal of Biological Macromolecules, 41, 266-273 (2007). https://doi.org/10.1016/j.ijbiomac.2007.03.002

[48] Marquardt D.: An algorithm for least-squares estimation of nonlinear parameters. Society for Industrial and Applied Mathematics, 11, 431-441 (1963). https://doi.org/10.1137/0111030

[49] Ghosh A., Clerens S., Deb-Choudhury S., Dyer J. M.: Thermal effects of ionic liquid dissolution on the structures and properties of regenerated wool keratin. Polymer Degradation and Stability, 108, 108-115 (2014). https://doi.org/10.1016/j.polymdegradstab.2014.06.007

[50] Hu X., Kaplan D., Cebe P.: Determining beta-sheet crystallinity in fibrous proteins by thermal analysis and infrared spectroscopy. Macromolecules, 39, 6161-6170 (2006). https://doi.org/10.1021/ma0610109

[51] Martin M. C., Schade U., Lerch P., Dumas P.: Recent applications and current trends in analytical chemistry using synchrotron-based Fourier-transform infrared microspectroscopy. TrAC Trends in Analytical Chemistry, 29, 453-463 (2010). https://doi.org/10.1016/j.trac.2010.03.002 
[52] Wojciechowska E., Włochowicz A., WesełuchaBirczyńska A.: Application of fourier-transform infrared and Raman spectroscopy to study degradation of the wool fiber keratin. Journal of Molecular Structure, 511, 307-318 (1999). https://doi.org/10.1016/S0022-2860(99)00173-8

[53] Lyman D. J., Murray-Wijelath J., Feughelman M.: Effect of temperature on the conformation of extended $\alpha$-keratin. Applied Spectroscopy, 55, 552-554 (2001). https://doi.org/10.1366/0003702011952343

[54] Aluigi A., Vineis C., Varesano A., Mazzuchetti G., Ferrero F., Tonin C.: Structure and properties of keratin/PEO blend nanofibres. European Polymer Journal, 44, 24652475 (2008).

https://doi.org/10.1016/j.eurpolymj.2008.06.004

[55] Cao J.: Melting study of the $\alpha$-form crystallites in human hair keratin by DSC. Thermochimica Acta, 335, 5-9 (1999).

https://doi.org/10.1016/S0040-6031(99)00055-6

[56] Ruoslahti E., Pierschbacher M. D.: New perspectives in cell adhesion: RGD and integrins. Science, 238, 491497 (1987).

https://doi.org/10.1126/science.2821619

[57] Aboushwareb T., Eberli D., Ward C., Broda C., Holcomb J., Atala A., van Dyke M.: A keratin biomaterial gel hemostat derived from human hair: Evaluation in a rabbit model of lethal liver injury. Journal of Biomedical Materials Research Part B: Applied Biomaterials, 90, 45-54 (2009).

https://doi.org/10.1002/jbm.b.31251
[58] Zoccola M., Aluigi A., Tonin C.: Characterisation of keratin biomass from butchery and wool industry wastes. Journal of Molecular Structure, 938, 35-40 (2009). https://doi.org/10.1016/j.molstruc.2009.08.036

[59] Onifade A. A., Al-Sane N. A., Al-Musallam A. A., AlZarban S.: A review: Potentials for biotechnological applications of keratin-degrading microorganisms and their enzymes for nutritional improvement of feathers and other keratins as livestock feed resources. Bioresource Technology, 66, 1-11 (1998). https://doi.org/10.1016/S0960-8524(98)00033-9

[60] Tonin C., Zoccola M., Aluigi A., Varesano A., Montarsolo A., Vineis C., Zimbardi F.: Study on the conversion of wool keratin by steam explosion. Biomacromolecules, 7, 3499-3504 (2006). https://doi.org/10.1021/bm060597w

[61] Rodriguez L. G., Wu X., Guan J-L.: Wound-healing assay. Methods in Molecular Biology, 294, 23-29 (2005).

[62] Fronza M., Heinzmann B., Hamburger M., Laufer S., Merfort I.: Determination of the wound healing effect of Calendula extracts using the scratch assay with $3 \mathrm{~T} 3$ fibroblasts. Journal of Ethnopharmacology, 126, 463467 (2009). https://doi.org/10.1016/j.jep.2009.09.014

[63] Aramwit P., Palapinyo S., Srichana T., Chottanapund S., Muangman P.: Silk sericin ameliorates wound healing and its clinical efficacy in burn wounds. Archives of Dermatological Research, 305, 585-594 (2013). https://doi.org/10.1007/s00403-013-1371-4 